Article

\title{
Sediment Deposition at the Caernarvon Crevasse during the Great Mississippi Flood of 1927: Implications for Coastal Restoration
}

\author{
John W. Day Jr. ${ }^{1}$, Jaye E. Cable ${ }^{2}$, Robert R. Lane ${ }^{1, *}$ and G. Paul Kemp ${ }^{1}$ \\ 1 Department of Oceanography and Coastal Sciences, School of the Coast and Environment, \\ Louisiana State University, Baton Rouge, LA 70803, USA; johnday@lsu.edu (J.W.D.J.); \\ gpkemp@lsu.edu (G.P.K.) \\ 2 Department of Marine Sciences, University of North Carolina-Chapel Hill, Chapel Hill, NC 27599, USA; \\ jecable@email.unc.edu \\ * Correspondence: rlane@lsu.edu; Tel.: +1-225-247-3917; Fax: +1-225-578-6226
}

Academic Editor: Y. Jun Xu

Received: 4 November 2015; Accepted: 15 January 2016; Published: 25 January 2016

\begin{abstract}
During the 1927 Mississippi flood, the levee was dynamited downstream of New Orleans creating a $2 \mathrm{~km}$ wide crevasse that inundated the Breton Sound estuary and deposited a crevasse splay of about $130 \mathrm{~km}^{2}$. We measured sediment deposition in the splay that consisted of a silty-clay layer bounded by aged peat below and living roots above. Based on coring, we developed a map of the crevasse splay. The clay layer ranged from 2 to $42 \mathrm{~cm}$ thick and occurred 24 to $55 \mathrm{~cm}$ below the surface. Bulk density of the clay layer decreased and soil organic matter increased with distance from the river. ${ }^{210} \mathrm{~Pb}_{\text {excess }}$ and ${ }^{137} \mathrm{Cs}$ dating an age of $\sim 1926-1929$ for the top of the layer. During the flood event, deposition was at least $22 \mathrm{~mm} \cdot \mathrm{month}^{-1}-10$ times the annual post-1927 deposition. The crevasse splay captured from $55 \%$ to $75 \%$ of suspended sediments that flowed in from the river. The 1927 crevasse deposition shows how pulsed flooding can enhance sediment capture efficiency and deposition and serves as an example for large planned diversions for Mississippi delta restoration.
\end{abstract}

Keywords: Mississippi delta restoration; diversions; 1927 flood; Breton Sound

\section{Introduction}

Approximately 25\% of wetlands in the Mississippi River delta plain have been lost since 1932, with a total land loss of $4900 \mathrm{~km}^{2}$ and a current rate of loss of 39 to $43 \mathrm{~km}^{2} \cdot \mathrm{year}^{-1}$ [1,2]. This wetland loss have been attributed to pervasive hydrologic alteration of the deltaic plain, herbivory, enhanced subsidence, salt-water intrusion, and creation of impoundments [3,4]. Underlying all of these causes is the separation of the delta from the Mississippi River by levees that confine the river channel and restrain seasonal flood waters [3,5-8]. We now understand the value of river floods that provide fresh water to reduce salinity stress, iron to complex with sulfide and reduce sulfide toxicity, mineral sediments to promote accretion, and nutrients to stimulate wetland productivity, which leads to organic soil formation [7,9-11]. Combating coastal erosion and restoring coastal wetlands is now a main component of State and Federal policy [12], and the construction of river diversions to reintroduce Mississippi River water and sediments into coastal basins is planned for the coming decade $[4,13,14]$. Understanding how historical floods and crevasse deposits built land will inform future restoration work as scientific research and engineering converge on the best approaches for coastal land-building. Our paper examines the 1927 flood crevasse deposition to understand the depth, volume and distribution of sediment flood deposits in Caernarvon, Louisiana. 
Late summer 1926 was the beginning of a meteorological event unprecedented in historical records for the Lower Mississippi River Valley, an event that culminated in the Mississippi River remaining above flood stage at St. Louis for six months from January to June 1927. Peak discharge of $2,470,000 \mathrm{ft}^{3} \cdot \mathrm{s}^{-1}\left(\sim 70,000 \mathrm{~m}^{3} \cdot \mathrm{s}^{-1}\right)$ was measured during May 1927 at Vicksburg, Mississippi [15,16], which was nearly four times the average mean flow of about $18,000 \mathrm{~m}^{3} \cdot \mathrm{s}^{-1}$. Heavy rainfall combined with snowmelt within the three major tributary basins, the upper Mississippi, Ohio, and Missouri Rivers, combined to make this the largest flood event on record and changed the course of history for the management of the Mississippi River and its delta. Sustained high waters on the lower river caused numerous levee failures and led to extensive flooding over nearly $70,000 \mathrm{~km}^{2}$ of the lower Mississippi alluvial valley. In Louisiana, extensive flooding occurred in the southern part of the state, and New Orleans appeared unlikely to escape a similar fate. River stage at New Orleans peaked at 21 feet $(6.9 \mathrm{~m})$ on 21 April 1927 (Figure 1), which stood in stark contrast to a city largely positioned below sea level with a peak elevation of about $3 \mathrm{~m}$ [15]. In an effort to lower river levels at New Orleans, a section of levee near Caernarvon, $22 \mathrm{~km}$ downriver from the city at river mile 81, was destroyed with dynamite (Figure 2). A 2-km wide opening resulted that allowed river water to flow for over three months into the Breton Sound estuary. Peak discharge through the breach was $9254 \mathrm{~m}^{3} \cdot \mathrm{s}^{-1}$, or about one seventh of peak river discharge [15-17].

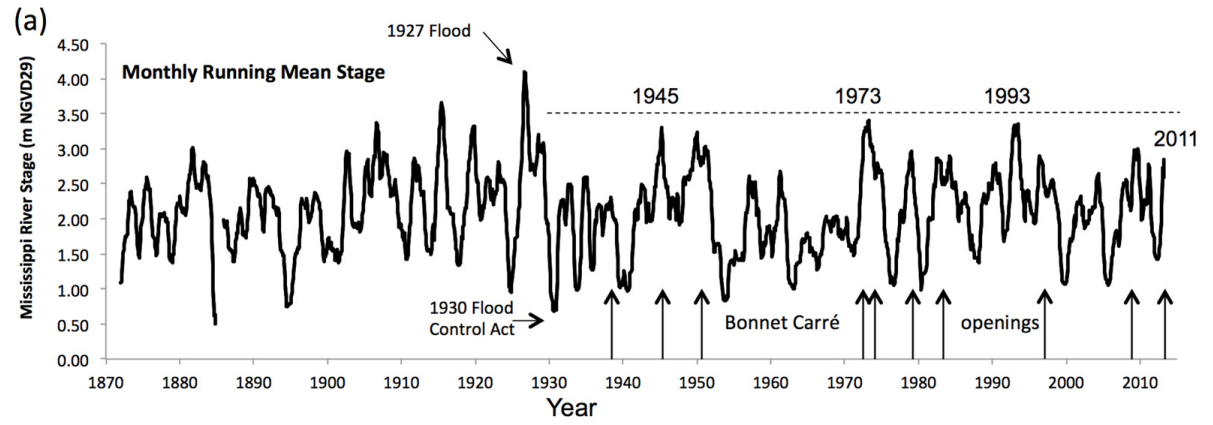

(b)

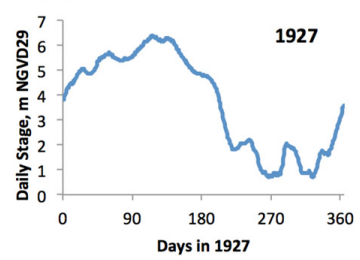

(c)

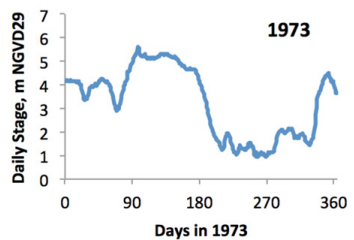

(d)

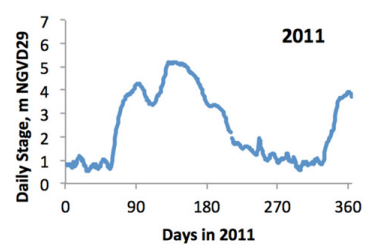

Figure 1. A monthly running mean of daily stage (m, NGVD29) at the Carrollton gauge, New Orleans, Louisiana, is shown from 1871 to 2011 for the Mississippi River (a); the 1927 flood was the highest recorded stage on the river in 132 years, exceeding the next highest stage in 1916 by over half a meter. Daily stage is shown for 1927 (b); 1973 (c); and 2011 (d) to illustrate the duration and variability in flood crest heights and timing for major flood years. After the implementation of flood control plans, the river never again crested as high as the 1927 flood.

The damage caused by floodwaters in the entire Lower Mississippi River Valley displaced over 900,000 people, or nearly one percent of the total U.S. population at the time, with 246 confirmed deaths and unofficial fatality estimates that exceeded 1000 [15]. Total property damage was estimated at $\$ 400$ million in 1927 (>\$4 billion in 21st century), exceeding the aggregate losses of all previous Mississippi River floods at the time. The flood had tremendous social, economic, and environmental consequences and led directly to the current flood control system, the Mississippi River and Tributaries Project [15]. After the 1927 flood, engineered structures were built, including $3500 \mathrm{~km}$ of high levees and several emergency spillway outlets, that have more effectively confined the river while also limiting maximum discharge past New Orleans (Figure 1c,d). Today, when the Mississippi River 
reaches about $5.1 \mathrm{~m}$ at New Orleans, the Bonnet Carré Spillway immediately upstream of the city is opened. With a capacity up to $9000 \mathrm{~m}^{3} \cdot \mathrm{s}^{-1}$, the spillway discharges river water across $>1300$ ha of cypress swamp before entering Lake Pontchartrain [6,18]. The Bonnet Carré Spillway has been opened 10 times since 1934 to prevent river stage at New Orleans from reaching pre-1927 levels [18].

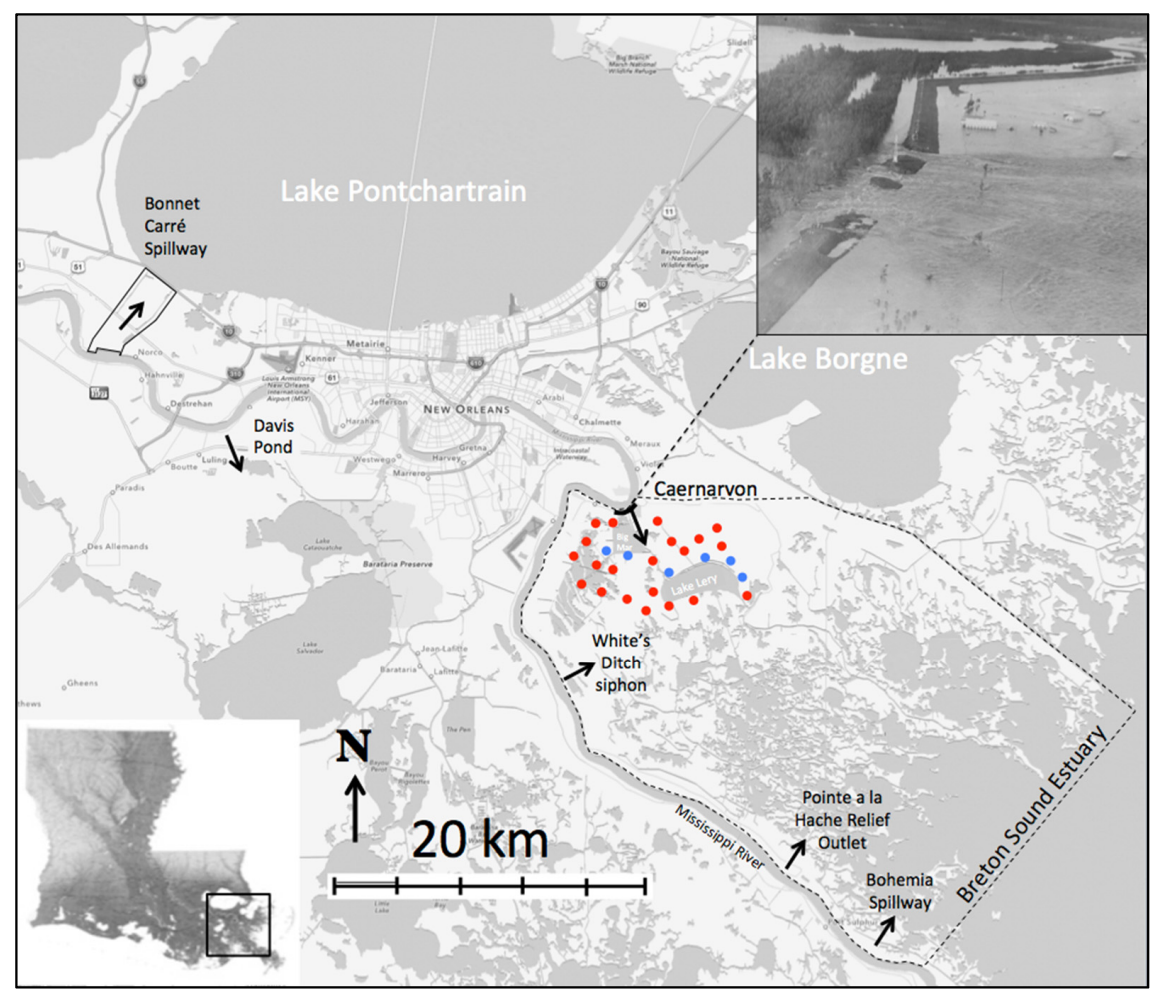

Figure 2. The Breton Sound estuary. Dots indicate where core samples were taken and the approximate area of the crevasse splay deposit based on our measurements. Blue dots indicate cores that had additional analysis carried out. Upper right inset: aerial photo showing Mississippi River water flowing through the 1927 Caernarvon levee breach. Dark black line at the site of the crevasse is the estimated width of the levee breach.

\section{Objectives and Hypothesis}

In August 1991, a river diversion structure was opened at Caernarvon, Louisiana, to channel Mississippi River water into the Breton Sound estuary. While carrying out research on the impacts of the diversion on water quality [19,20] and wetland elevation [21], a distinctive silty-clay layer (hereafter referred to as the clay layer) was discovered in the vicinity of the 1927 crevasse. We hypothesized that the clay layer was associated with the 1927 flood, and furthermore, that it would be thickest near the site of the 1927 breach and that dating would be coincident with the time of the flood. Our objective in this paper is to investigate the clay layer spatial extent in the upper basin near the former levee breach and date the deposit using ${ }^{210} \mathrm{~Pb}$ geochronology.

\section{Study Area}

The study site is located in the upper Breton Sound estuary, an area of about $1100 \mathrm{~km}^{2}$ of fresh, brackish, and saline wetlands interspersed with open waterbodies. The estuary is part of the St. Bernard delta complex, which was formed between 4000 and 2000 years ago, as well as the Plaquemines-Balize delta complex, which was formed during the last $\sim 1300$ years [22]. Since then, approximately half of the original wetlands have disappeared by the processes of shore-line erosion and coastal subsidence [23] exacerbated by human activity [3,5]. Numerous natural crevasses and 
minor distributaries as well as seasonal overbank flooding occurred along the lower Mississippi River prior to human manipulation [24-26]. The upper perimeter of the Breton Sound estuary was fringed by 1 to $3 \mathrm{~km}$ of freshwater forested wetlands (i.e., see USGS St. Bernard map 1892). Regular Mississippi River flow into the estuary decreased with the construction of flood control levees soon after the colonization of New Orleans by the French in 1719 [27]. However, major riverine inputs to the estuary still occurred via crevasses, minor distributaries, and overbank flooding throughout the first quarter of the twentieth century [25], such as the $335 \mathrm{~m}$ wide crevasse at Poydras near Caernarvon in 1922 that resulted in a flow of $13,014 \mathrm{~m}^{3} \cdot \mathrm{s}^{-1}$ and scoured a 90-foot deep scour hole still present today $1.3 \mathrm{~km}$ east of the Caernarvon structure [28]. The 1927 flood crevasse was closed in 1928, and river flow to the basin is now prevented by levees with exception of the Caernarvon freshwater diversion structure, White's Ditch siphon, the Pointe a la Hache Relief Outlet, and the Bohemia Spillway all of which discharge about 100 times less than the 1927 crevasse and are spread over a 45-km distance along the western edge of the basin [29]. The Caernarvon diversion structure, with a maximum discharge rate of $226 \mathrm{~m}^{3} \cdot \mathrm{s}^{-1}$, was opened in August 1991 [29].

\section{Methods}

Sediment cores were collected pre-Hurricane Katrina in the basin to map the areal extent of flood deposits and to confirm the age of the flood deposit using ${ }^{210} \mathrm{~Pb}_{\text {excess }}$ and ${ }^{137} \mathrm{Cs}$ geochronology (Figure 2). During March to July 1998, twenty-seven 1-m deep cores were collected using a McAuley coring device at the outfall area of the present-day Caernarvon diversion and the 1927 Caernarvon levee breach. Cores were collected at an increasing radius from the locus of the original levee break until the layer could no longer be visually distinguished. The corer allowed extraction of soft organic-rich marsh sediments with minimal disturbance or compaction. Cores were described geologically and photographed in the field at the time of extraction when color contrasts were greatest with particular attention given to the depth to and thickness of the silty-clay layer associated with the 1927 event.

Six of the cores were sampled for more detailed laboratory analysis of sediment properties, specifically bulk density (from dry weight; [30]) and organic matter content (loss on ignition; [31]) of representative layers above, within, and below the clay layer. A map of the clay layer deposit was constructed from sediment sampling in a $15 \mathrm{~km}$ radius from the site of the 1927 levee breach that included all cores where the clay layer was visually distinguishable in the sediments. The volume of the depositional layer was estimated, and the dry weight of the sediments contained in this volume was calculated based on representative values for the bulk density and organic matter content. We studied old maps and photos of the area and measured water depths of water bodies in the vicinity of the 1927 breach to determine if there were scour holes associated with the 1927 event.

Although the extent of the flood deposit layer, its depth below the marsh surface, its composition, and its thinning with distance from the site of the levee breach indicated that the layer was from the 1927 flood breach, we collected a soil core to determine if the layer could be dated to 1927 . A single sediment push core (7-cm ID) was collected that extended from the soil surface to below the crevasse deposit in the upper basin and sectioned at 1-cm intervals. Each section was dried, homogenized, packed into 10-mm diameter vials, and sealed. After three weeks ingrowth for secular equilibrium between ${ }^{226} \mathrm{Ra}$ and daughters, the sediments were counted on a well germanium detector for ${ }^{210} \mathrm{~Pb},{ }^{137} \mathrm{Cs}$, and ${ }^{226} \mathrm{Ra}$ daughters to estimate the age of the sediment at the top of the clay layer. $\mathrm{Pb}-210\left(\mathrm{t}_{1 / 2}=22.3 \mathrm{y}\right)$ was corrected for its parent, ${ }^{226} \mathrm{Ra}\left(\mathrm{t}_{1 / 2}=1620 \mathrm{y}\right)$, to obtain the unsupported ${ }^{210} \mathrm{~Pb}\left({ }^{210} \mathrm{~Pb}\right.$ excess $)$ required for dating. Sediment self-absorption of gamma rays was accounted for using methods outlined by Cutshall et al. [32]. The constant flux:constant supply (CF:CS) model was employed to estimate the sediment ages within the core [33].

\section{Results}

A scour hole was not evident from examination of historical maps and photos, and field investigation of the water bodies directly in the path of the levee breach revealed only shallow 
$(<2 \mathrm{~m})$ water depths. Thus we concluded that the depositional layer in the wetlands was not scoured from the natural levee. The silty-clay layer was visually distinguishable in 23 cores to a distance of $12 \mathrm{~km}$ from the point of the 1927 levee break. Heavily rooted marsh soils occurred above the clay layer, which was underlain by an aged peat. A maximum thickness of $42 \mathrm{~cm}$ was observed at $7 \mathrm{~km}$ from the break adjacent to the southeast corner of Lake Lery. Where present, the top of the layer occurred between 24 and $55 \mathrm{~cm}$ below the marsh surface, with an average depth of $35 \mathrm{~cm}$, yielding an average rate of aggradation post 1927 of $5 \mathrm{~mm} \cdot$ year $^{-1}$. The Caernarvon crevasse deposit is distinctly different from the marsh deposits above and below the layer. In the six cores from which bulk density and percent organic matter values were measured, the fresh marsh soil below the silty-clay layer was a poorly consolidated peat with a bulk density ranging from 0.08 to $0.13 \mathrm{~g} \cdot \mathrm{cm}^{-3}$, and an organic matter content from $50 \%$ to $80 \%$. The brackish marsh soil above the crevasse deposit was better consolidated with bulk density of 0.22 to $0.54 \mathrm{~g} \cdot \mathrm{cm}^{-3}$ and organic matter content of $10 \%$ to $35 \%$. The highest bulk densities $\left(0.22\right.$ to $\left.1.00 \mathrm{~g} \cdot \mathrm{cm}^{-3}\right)$ and lowest organic matter contents ( $4 \%$ to $25 \%$ ) of each of the sampled cores occurred in the clay deposit layer. The bulk density of the crevasse layer was inversely related to the distance from the levee breach (Figure 3a). Percent organic matter (Figure 3b) was positively related to distance.
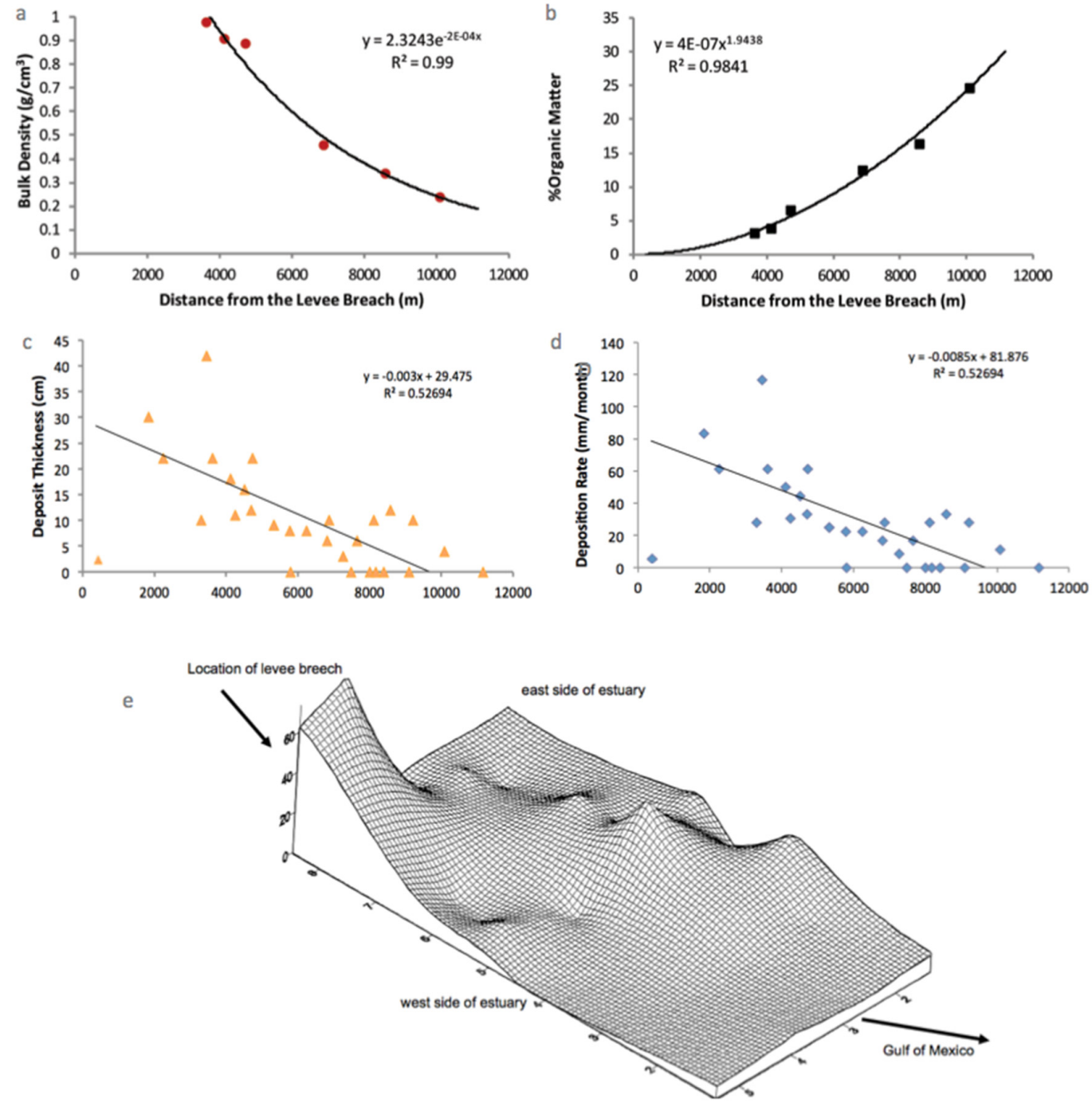

Figure 3. With distance from the levee breach are shown (a) dry bulk density; (b) organic matter content (\%); (c) thickness $(\mathrm{cm})$ of the silty-clay layer; $(\mathbf{d})$ deposition rate $\left(\mathrm{mm} \cdot \mathrm{month}^{-1}\right)$ for 6 cores; (e) the crevasse splay deposit based on measurements of silty-clay layer, which has area of $130 \mathrm{~km}^{2}$. 
The clay layer ranged from 2 to $42 \mathrm{~cm}$ thick and occurred between 24 and $55 \mathrm{~cm}$ below the sediment surface (Figure 3c). Deposition rates ranged from 5.6 to $117 \mathrm{~mm} \cdot \mathrm{month}^{-1}$ (37 $\pm 26 \mathrm{~mm} \cdot \mathrm{month}^{-1}$, mean \pm 1 .e.) within the crevasse deposit coring array (Figure 3d). The zone of deposition was greatest at the crevasse head and decreased with increasing distance until it was no longer visually discernible about $12 \mathrm{~km}$ south of the breach. Based on the thickness of the clay layer depositional wedge, an integrated volume of $2.79 \times 10^{7} \mathrm{~m}^{3}$ of sediments were deposited within the $130 \mathrm{~km}^{2}$ crevasse splay during the 1927 flood (Figure 3e). Using the average measured sediment dry bulk density of this layer of $0.98 \mathrm{~g} \cdot \mathrm{cm}^{-3}$, we estimate $2.74 \times 10^{10} \mathrm{~kg}$ sediments are present within the crevasse splay layer. This value of bulk density is for the current silty-clay deposit. There was likely some compression since 1927, but we used the total amount of mineral material in the layer to calculate the total weight of deposited sediments. This would not have been affected by compression. The 1927 artificial crevasse was active for a 3.6 month period [17]. Water discharge through the breach averaged $7800 \mathrm{~m}^{3} \cdot \mathrm{s}^{-1}$ for 108 days and yielded a total volume of water of $7.3 \times 10^{10} \mathrm{~m}^{3}[15,17]$. Peak discharge was $9254 \mathrm{~m}^{3} \cdot \mathrm{s}^{-1}$. Estimates of annual sediment loads in the river from 1881 to 1911 averaged $402 \times 10^{6} \mathrm{~m}^{3}$ over a 30-year period [34], while modeled suspended sediment concentrations of the flood stage of the river range from 500 to $675 \mathrm{mg} \cdot \mathrm{L}^{-1}$ around $1927[35,36]$. Based on these modeled concentrations, the sediment load entering the Caernarvon crevasse in 1927 ranged 3.63 to $4.91 \times 10^{10} \mathrm{~kg}$ with a volume of 3.71 to $5.01 \times 10^{7} \mathrm{~m}^{3}$ assuming a bulk density of $0.98 \mathrm{~g} \cdot \mathrm{cm}^{-3}$, which is higher but relatively close to what we calculated based on core measurements (i.e., $2.74 \times 10^{10} \mathrm{~kg}$ and $2.79 \times 10^{7} \mathrm{~m}^{3}$ ). Given sediment concentrations of 500 and $675 \mathrm{mg} \cdot \mathrm{L}^{-1}$, the capture efficiency ranged from $55 \%$ to $75 \%$ during the flood event.

The ${ }^{210} \mathrm{~Pb}_{\text {excess }}$ analysis of the top of the clay layer at $15 \mathrm{~cm}$ depth revealed an age of $\sim 1926-1929$, while rapid (3.6 months) deposition of $80 \mathrm{~mm}$ occurred below this depth (16 to $24 \mathrm{~cm}$ clay thickness in this core; Figure 4) shown as mixing in the ${ }^{210} \mathrm{~Pb}$ profile. During the flood event, deposition was at least $22 \mathrm{~mm} \cdot \mathrm{month}^{-1}$ based in the clay layer in this core-equivalent to $264 \mathrm{~mm} \cdot$ year $^{-1}$.

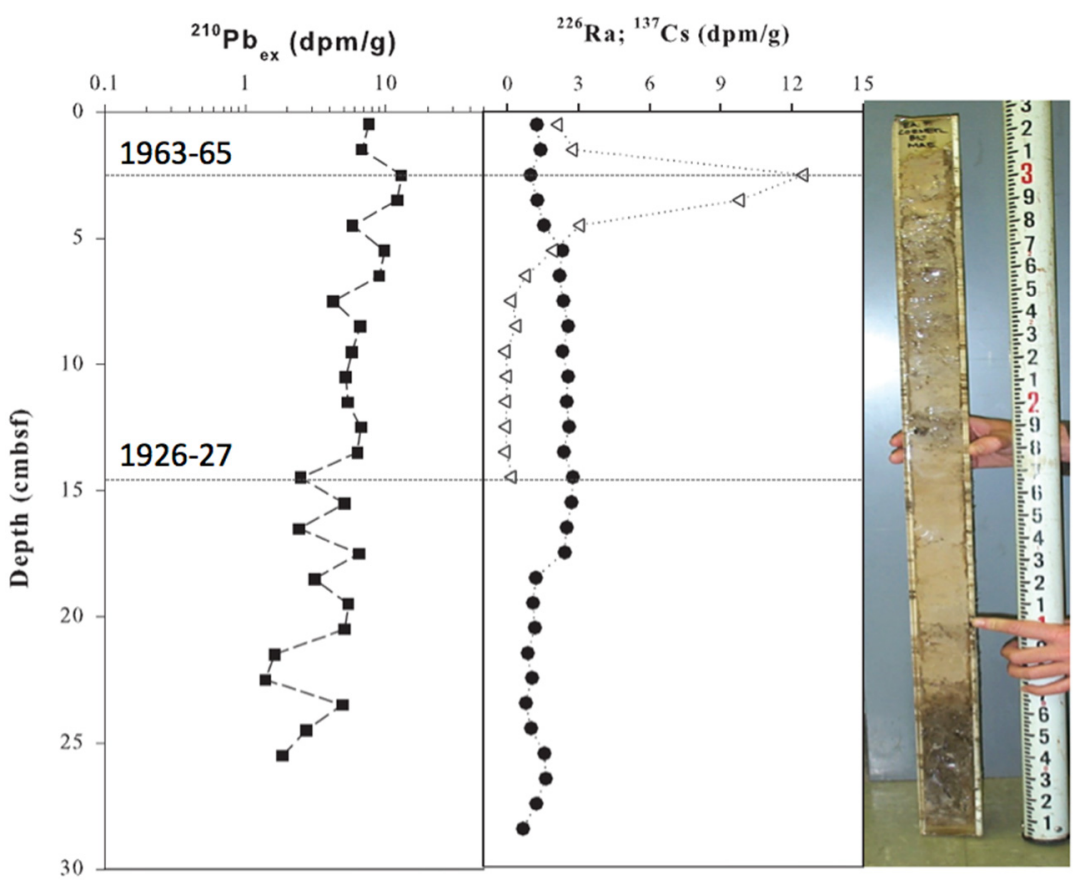

Figure 4. Recent accretion rates were estimated using ${ }^{210} \mathrm{~Pb}$ ex (left) and ${ }^{137} \mathrm{Cs}$ (middle) dating to isolate the sediment layer associated with 1927 flood deposition (right). The top of the sediment layer occured at $15 \mathrm{~cm}$, which is about 1926-1927. Above the sediment layer, accretion rates were about 2.5-3.0 mm year $^{-1}$ for this location. 


\section{Discussion}

In the Mississippi delta, hundreds of crevasses have been identified along distributary channels that overlap to form a continuous band of crevasse deposits essential to the formation and maintenance of both natural levees and coastal wetlands [25,28,34,37,38]. Our measurements indicate that the area of the crevasse splay at Caernarvon was about $130 \mathrm{~km}^{2}$. The artificial 1927 crevasse was similar in size and duration to naturally occurring historical crevasses. For example, the Davis Pond crevasse located on the west bank of the river upriver of New Orleans, which was active in the second half of the 19th century, is between 150 and $200 \mathrm{~km}^{2}$. The crevasse splay is still clearly visible on photos of the area. The Bonnet Carré crevasse, which was active from 1849 to 1882, created a large depositional sediment fan in wetlands and up to two meters of deposition in western Lake Pontchartrain [25]. The Bonnet Carré Spillway is probably the closest modern analog to the 1927 crevasse. The floodway has been opened 10 times since the 1930s (about once a decade and representing about 1\% of the time since it was completed in 1933; an opening is likely in early 2016) with flows ranging from 3000 to $9000 \mathrm{~m}^{3} \cdot \mathrm{s}^{-1}$, and accretion rates in the spillway average about $25 \mathrm{~mm} \cdot$ year $^{-1}$ compared to about $4 \mathrm{~mm} \cdot$ year $^{-1}$ in adjacent wetlands without river input [6,18]. Total fine grained sediment deposition in wetlands within the spillway near Lake Pontchartrain is as high as $2 \mathrm{~m}$ or an average of about $200 \mathrm{~mm}$ for each flood event.

Our results for sediment accretion rates before and after the 1927 event are similar to other reports of accretion for the Mississippi delta. We measured sediment deposition since the 1927 flood of between 2.5 and $3.0 \mathrm{~mm} \cdot$ year $^{-1}$. Other measurements of accretion at Caernarvon range from 2.5 to $<10 \mathrm{~mm} \cdot$ year $^{-1}[5,21,39]$. Accretion is highly variable throughout the Mississippi delta, with negative values at areas that are eroding to very high rates near major riverine sources [40], such as the Atchafalaya Delta, which is accreting up to $14 \mathrm{~mm} \cdot$ year $^{-1}$ [41].

While large floods are episodic, the 1927 Caernarvon crevasse illustrates their land-building potential can be much higher than current diversions that discharge less than $200 \mathrm{~m}^{3} \cdot \mathrm{s}^{-1}$ [5]. Given relative sea level rise estimates for the northern Gulf of Mexico and coastal Louisiana of 5.5 to $9.7 \mathrm{~mm} \cdot$ year $^{-1}$ (e.g., [42]), the land-building potential of a diversion as small as the Caernarvon diversion is limited. Snedden et al. [43] demonstrated that the sediment discharge through the Caernarvon diversion yielded deposition rates of about $0.65 \mathrm{~mm} \cdot$ year $^{-1}$ between 2002 and 2003, which is 4 times less than the long-term rate of 2.5 to $3.0 \mathrm{~mm} \cdot$ year $^{-1}$. Since Hurricane Katrina in 2005, a small new delta has formed in Big Mar, a shallow pond that resulted from a failed agricultural impoundment. Over the last two decades the delta in Big Mar has grown to almost 250 ha, with about 235 ha of those acres forming in the10 years after Katrina [44]. However, under historical conditions of prolonged high sediment yield discharge during a flood event, such as occurred in 1927 in the same location as the modern diversion, the impact on land-building is much more dramatic.

Before river embankment became widespread in many of the world's rivers, overbank flooding and crevasses were important and common mechanisms for replenishing floodplain and delta sediments and fertilizing the landscape [24,25,28,45-47]. Crevasses function during high water via temporary channels through low points along the natural levee, forming crevasse splays, which have areas on the order of 10 to $100 \mathrm{~s}$ of $\mathrm{km}^{2}$ compared to 100 to $1000 \mathrm{~s}$ of $\mathrm{km}^{2}$ for full deltaic lobes [26,38,48]. These processes of floodplain and delta inundation and draining have built land along river corridors and in deltas around the world [38,46,48-51]. Where levees have not stopped river floods, overbank flooding still occurs, such as in the Danube [52], northwestern Mediterranean deltas [53] and for the Atchafalaya delta of the Mississippi [48], and leads to more sustainable wetlands. There is a general consensus that major world deltas will become smaller in the 21st century due to accelerated sea-level rise and a reduction in sediment input (e.g., [54]). Thus, it seems clear that the Mississippi delta will be considerably smaller by the end of the century. Our results indicate that the use of episodic large inputs of river water would lead to maximizing the area of deltaic wetlands. 
Human impacts on deltas globally have led to widespread deterioration and unsustainability $[45,46]$. The combined effects of land use change and climate change make clear the need for new paradigms in how humans manage and restore deltas. Tessler et al. [55] reported that the combination of land use changes, climate change, and increasing energy costs will increase risks significantly of non-sustainable outcomes, especially in first world countries such as restoration and management of the Mississippi and Rhine deltas. Given predictions of accelerated sea level rise, increasing human impacts, and growing energy scarcity $[13,42,56,57]$, delta restoration should be aggressive and large scale. We believe that restoration of the Mississippi delta will require diversions similar in scale to historical crevasses if they are to be most effective. Such large episodic diversions may help to alleviate a growing problem associated with proposed diversions in the Mississippi delta. Because continuous inputs of river water result in near permanent freshening in some locations, strong opposition has developed to diversions in local fishing communities due to the displacement of local fisheries worth hundreds of millions of dollars [58]. The periodic opening of the Bonnet Carré Spillway and the 1927 crevasse at Caernarvon serve as good models for understanding the significance of this fishery concern. The periodic openings have minimized algal blooms to short periods [59] and resulted in larger fisheries catches in years following openings [60]. Large, episodic introductions of river water would also help alleviate the impacts of projected increases in large river floods [61] and the frequency of category 3 and 4 hurricanes [62,63]. Operation of large diversions during major floods could both reduce the pressure on levees, as in the case of the Bonnet Carré Spillway, and lead to large episodic land building events. These would enhance hurricane protection, especially if restoration of cypress swamps were undertaken in the fresh portions of the crevasse splay area. Early maps show that there was a fringe of swamps several $\mathrm{km}$ wide in the upper Breton Sound estuary at the beginning of the 20th century. In contrast, if no action is taken, the transportation and oil and gas infrastructure critical to national interests of shipping, trade, and energy, as well as the high value of ecosystem goods and services of the delta will be undermined and ultimately lost $[58,64]$. The cost to not saving the land that supports all of these critical economic functions, seafood, energy, shipping, are prohibitive in the long term, and large diversions must be part of any coordinated effort to maintain the Mississippi delta [64]. Given the global scale of deteriorating deltas threatened by sea-level rise and economic vitality of these regions [45,54], forging a solution that utilizes the full capacity of the river may be the best outcome we have available.

\section{Conclusions}

We measured the extent, sedimentary characteristics, and age of a crevasse splay located where an artificial breach in the levee was created during the 1927 flood of the Mississippi River. The thickness and depth of the deposit was measured by repeated coring in the area where the splay was located. The deposit covered about $130 \mathrm{~km}^{2}$ and was wedge shaped with the thickest part located near the site of the levee breach. The thickness of the clay layer ranged from 2 to $42 \mathrm{~cm}$ and occurred 24 to $55 \mathrm{~cm}$ below the surface. Bulk density of the clay layer decreased and organic matter increased with distance from the river. ${ }^{210} \mathrm{~Pb}_{\text {excess }}$ and ${ }^{137} \mathrm{Cs}$ dating indicated that the layer was deposited about 1926-1929. The deposition rate of the clay layer was $22 \mathrm{~mm} \cdot \mathrm{month}^{-1}-10$ times the annual post-1927 deposition of 2.6 to $3.0 \mathrm{~mm}$. year ${ }^{-1}$. We calculated that the crevasse splay captured from $55 \%$ to $75 \%$ of suspended sediments that flowed in from the river. The 1927 crevasse deposition shows how pulsed flooding can enhance sediment deposition efficiency in deltaic environments and serves as an example for large planned diversions for Mississippi delta restoration.

Acknowledgments: USEPA Water and Watersheds (\#R828009) and Louisiana Department of Natural Resources (\#2503-01-27) funding supported this work. Assistance from Emily Keenan, Kate Clark, Charles Reulet, and Erick Swenson is gratefully acknowledged. 
Author Contributions: J.W.D. and G.P.K. conceived of the idea for the project and added R.R.L., who carried out all field collection of clay layer cores for the sediment wedge analysis; R.R.L. also analyzed the sediments in the lab and carried out statistical analysis. J.E.C. and J.W.D. wrote the paper, with contributions from G.P.K. and R.R.L.; J.E.C. made the sediment budget calculations, collected and analyzed sediment for geochronology, compiled the stage data, and assisted with figure development. J.W.D., G.W.P., and R.R.L. contributed to sediment budget calculations.

Conflicts of Interest: The authors declare no conflict of interest.

\section{References}

1. Barras, J.A.; Bernier, J.C.; Morton, R.A. Land Area Change in Coastal Louisiana-A Multidecadal Perspective (from 1956 to 2006): U.S. Geological Survey Scientific Investigations Map 3019, Scale 1:250,000; United States Geological Survey: Reston, VA, USA, 2008; p. 14.

2. Couvillion, B.R.; Barras, J.A.; Steyer, G.D.; Sleavin, W.; Fischer, M.; Beck, H.; Trahan, N.; Griffin, B.; Heckman, D. Land Area Change in Coastal Louisiana from 1932 to 2010: U.S. Geological Survey Scientific Investigations Map 3164, Scale 1:265,000; United States Geological Survey: Reston, VA, USA, 2011; p. 12.

3. Day, J.W.; Britsch, L.D.; Hawes, S.; Shaffer, G.; Reed, D.J.; Cahoon, D. Pattern and process of land loss in the Mississippi Delta: A spatial and temporal analysis of wetland habitat change. Estuaries 2000, 23, 425-438. [CrossRef]

4. Day, J.W.; Boesch, D.F.; Clairain, E.J.; Kemp, G.P.; Laska, S.B.; Mitsch, W.J.; Orth, K.; Mashriqui, H.; Reed, D.J.; Shabman, L.; et al. Restoration of the Mississippi Delta: Lessons from Hurricanes Katrina and Rita. Science 2007, 315, 1679-1684. [PubMed]

5. Day, J.W.; Cable, J.E.; Cowan, J.H.; DeLaune, R.; Fry, B.; Mashriqui, H.; Justic, D.; Kemp, P.; Lane, R.R.; Rick, J.; et al. The impacts of pulsed reintroduction of river water on a Mississippi Delta coastal basin. J. Coast. Res. 2009, 54, 225-243.

6. Nittrouer, J.A.; Best, J.L.; Brantley, C.; Cash, R.W.; Czapiga, M.; Kumar, P.; Parker, G. Mitigating land loss in coastal Louisiana by controlled diversion of Mississippi River sand. Nat. Geosci. 2012, 5, 534-537. [CrossRef]

7. Nyman, J.A. Integrating successional ecology and the delta lobe cycle in wetland research and restoration. Estuar. Coasts 2014, 37, 1490-1505. [CrossRef]

8. Paola, C.; Twilley, R.R.; Edmonds, D.A.; Kim, W.; Mohrig, D.; Parker, G.; Viparelli, E.; Voller, V.R. Natural processes in delta restoration: Application to the Mississippi delta. Ann. Rev. Mar. Sci. 2010, 3, 67-91. [CrossRef] [PubMed]

9. Mendelssohn, I.A.; Morris, J.T. Eco-physiological controls on the productivity of Spartina alterniflora loisel. In Concepts and Controversies in Tidal Marsh Ecology; Weinstein, M.P., Kreeger, D.A., Eds.; Kuwer Acedemic Publishers: Boston, MA, USA, 2000; pp. 59-80.

10. Morris, J.T.; Shaffer, G.P.; Nyman, J.A. Brinson review: Perspectives on the influence of nutrients on the sustainability of coastal wetlands. Wetlands 2013, 33, 975-988. [CrossRef]

11. Twilley, R.R.; Rivera-Monroy, V. Sediment and nutrient tradeoffs in restoring Mississippi river delta: Restoration vs. eutrophication. Contemp. Water Res. Educ. 2009, 141, 39-44. [CrossRef]

12. Coastal Protection and Restoration Authority (CPRA). Louisiana's Comprehensive Master Plan for a Sustainable Coast; Coastal Protection and Restoration Authority: Baton Rouge, LA, USA, 2012; p. 392.

13. Day, J.W.; Kemp, G.P.; Freeman, A.M.; Muth, D. Perspectives on the Restoration of the Mississippi Delta: The Once and Future Delta; Springer: New York, NY, USA, 2014; p. 195.

14. Wang, H.; Steyer, G.D.; Couvillion, B.R.; Rybczyk, J.M.; Beck, H.J.; Sleavin, W.J.; Meselhe, E.A.; Allison, M.A.; Boustany, R.G.; Fischenich, C.J.; et al. Forecasting landscape effects of Mississippi River diversions on elevation and accretion in Louisiana deltaic wetlands under future environmental uncertainty scenarios. Estuar. Coast. Shelf Sci. 2014, 138, 57-68.

15. Barry, J.M. Rising Tide: The Great Mississippi Flood of 1927 and How it Changed America; Simon and Schuster: New York, NY, USA, 1997; p. 507.

16. O'Connor, J.E.; Costa, J.E. The World's Largest Floods, Past and Present-Their Causes and Magnitudes; U.S. Geological Survey: Reston, VA, USA, 2004; p. 13.

17. United States Corps of Engineers (USCOE). Results of Discharge Observations Mississippi River and its Tributaries and Outlets, 1924-1930; Mississippi River Commission: Vicksburg, MA, USA, 1930; p. 100. 
18. Day, J.W.; Hunter, R.; Keim, R.F.; DeLaune, R.; Shaffer, G.; Evers, E.; Reed, D.J.; Brantley, C.; Kemp, P.; Day, J.; et al. Ecological response of forested wetlands with and without Large-Scale Mississippi River input: Implications for management. Ecol. Eng. 2012, 46, 57-67.

19. Lane, R.R.; Day, J.W.; Justic, D.; Reyes, E.; Day, J.N.; Hyfield, E. Changes in stoichiometric Si, N and P ratios of Mississippi River water diverted through coastal wetlands to the Gulf of Mexico. Estuar. Coast. Shelf Sci. 2004, 60, 1-10. [CrossRef]

20. Lane, R.R.; Day, J.W.; Marx, B.; Hyfield, E.; Day, J.N.; Reyes, E. The effects of riverine discharge on temperature, salinity, suspended sediment and chlorophyll a in a Mississippi delta estuary measured using a flow-through system. Estuar. Coast. Shelf Sci. 2007, 74, 145-154. [CrossRef]

21. Lane, R.R.; Day, J.W.; Day, J.N. Wetland surface elevation, vertical accretion, and subsidence at three Louisiana estuaries receiving diverted Mississippi River water. Wetlands 2006, 26, 1130-1142. [CrossRef]

22. Blum, M.D.; Roberts, H.H. The Mississippi delta region: Past, present, and future. Ann. Rev. Earth Planet. Sci. 2012, 40, 655-683. [CrossRef]

23. Yuill, B.; Lavoie, D.; Reed, D.J. Understanding subsidence processes in coastal Louisiana. J. Coast. Res. Spec. Issue 2009, 54, 23-36. [CrossRef]

24. Condrey, R.E.; Hoffman, P.E.; Evers, D.E. The last naturally active delta complexes of the Mississippi River (LNDM): Discovery and implications. In Perspectives on the Restoration of the Mississippi Delta; Day, J., Kemp, P., Freeman, A., Muth, D., Eds.; Springer: New York, NY, USA, 2014; pp. 33-50.

25. Saucier, R.T. Recent Geomorphic History of the Pontchartrain Basin; Louisiana State University Press: Baton Rouge, LA, USA, 1963; p. 114.

26. Welder, F.A. Processes of Deltaic Sedimentation in the Lower Mississippi River; Coastal Studies Institute Technical Report 12; Louisiana State University: Baton Rouge, LA, USA, 1959; pp. 1-90.

27. Colten, C. Transforming New Orleans and Its Environs: Centuries of Change; University of Pittsburgh Press: Pittsburgh, PA, USA, 2001; p. 288.

28. Davis, D.W. Crevasses on the lower course of the Mississippi River. In Coastal Zone'93, Eighth Symposium on Coastal and Ocean Management; American Society of Civil Engineers: Reston, VA, USA, 1993; pp. 360-378.

29. Lane, R.R.; Day, J.W.; Thibodeaux, B. Water quality analysis of a freshwater diversion at Caernarvon, Louisiana. Estuaries 1999, 2, 327-336. [CrossRef]

30. Burt, R. Soil Survey Laboratory Information Manual; Soil Survey Investigations Report No. 45, Version 2.0. U.S. Department of Agriculture, Natural Resources Conservation Service (NRCS): Portland, OR, USA, 2011.

31. Heiri, O.; Lotter, A.F.; Lemcke, G. Loss on ignition as a method for estimating organic and carbonate content in sediments: Reproducibility and comparability of results. J. Paleolimnol. 2001, 25, 101-110. [CrossRef]

32. Cutshall, N.H.; Larsen, I.L.; Olsen, C.R. Direct analysis of ${ }^{210} \mathrm{~Pb}$ in sediment samples: Self absorption corrections. Nucl. Instrum. Methods 1983, 206, 1-20. [CrossRef]

33. Appleby, P.G.; Oldfield, F. Applications of Pb-210 to sedimentation studies. In Uranium-series Disequilibrium: Applications to Earth, Marine, and Environmental Sciences, 2nd ed.; Ivanovich, M., Harmon, R.S., Eds.; Clarendon Press: Oxford, UK, 1992; pp. 731-778.

34. Kesel, R.H. The decline in the suspended load of the lower Mississippi River and its influence on adjacent wetlands. Environ. Geol. Water Sci. 1988, 11, 271-281. [CrossRef]

35. Mossa, J. Sediment dynamics in the lowermost Mississippi River. Eng. Geol. 1996, 45, 457-479. [CrossRef]

36. Tweel, A.W.; Turner, R.E. Watershed land use and river engineering drive wetland formation and loss in the Mississippi River birdfoot delta. Limnol. Oceanogr. 2012, 57, 18-28. [CrossRef]

37. Elliot, D.O. The Improvement of the Lower Mississippi River for Flood Control and Navigation, War Department-Corps of Engineers; U.S. Waterways Experiment Station: Vicksburg, MS, USA, 1932.

38. Kesel, R.H. Human modifications to the sediment regime in the lower Mississippi River flood plain. Geomorphology 2003, 56, 325-334. [CrossRef]

39. DeLaune, R.D.; Jugsujinda, A.; Peterson, G.W.; Patrick, W.H. Impact of Mississippi River freshwater reintroduction on enhancing marsh accretionary processes in a Louisiana estuary. Estuar. Coast. Shelf Sci. 2003, 58, 653-662. [CrossRef]

40. Nyman, J.A.; Delaune, R.D.; Patrick, W.H. Wetland soil formation in the rapidly subsiding Mississippi River deltaic plain: Mineral and organic matter relationships. Estuar. Coast. Shelf Sci. 1990, 31, 57-69. [CrossRef] 
41. DeLaune, R.D.; Smith, C.J.; W.H. Partick, Jr.; Roberts, H.H. Rejuvanated marsh and bay-bottom accretion on rapidly subsiding coastal plain of U.S. gulf coast: A second-order effect of the emerging Atchafalaya delta. Estuar. Coast. Shelf Sci. 1987, 25, 381-389.

42. Williams, J.; Ismail, N. Climate change, coastal vulnerability and the need for adaptation alternatives: Planning and design examples from Egypt and the USA. J. Mar. Sci. Eng. 2015, 3, 591-606. [CrossRef]

43. Snedden, G.A.; Cable, J.E.; Swarzenski, C.M.; Swenson, E.M. Sediment discharge into a subsiding Louisiana deltaic estuary through a Mississippi River diversion. Estuar. Coast. Shelf Sci. 2007, 71, 181-193. [CrossRef]

44. Lopez, J.; Henkel, T.; Moshogianis, A.; Baker, A.; Boyd, E.; Hillmann, E.; Connor, P.; Baker, D.B. Examination of deltaic processes of Mississippi River outlets-Caernarvon Delta and Bohemia Spillway in Southeast Louisiana. Gulf Coast Assoc. Geol. Sci. Trans. 2014, 64, 707-708.

45. Syvitski, J.P.M.; Kettner, A.J.; Overeem, I.; Hutton, E.W.H.; Hannon, M.T.; Brankenridge, G.R.; Day, G.R.; Vorosmarty, C.; Saito, Y.; Giosan, L.; et al. Sinking deltas due to human activities. Nat. Geosci. 2009, 2, 682-686.

46. Vörösmarty, C.J.; Syvitski, J.; Day, J.W.; de Sherbinin, A.; Giosan, L.; Paola, C. Battling to save the world's river deltas. Bull. At. Sci. 2009, 65, 31-43. [CrossRef]

47. Shen, Z.; Törnqvist, T.E.; Mauz, B.; Chamberlain, E.L.; Nijhuis, A.G.; Sandoval, L. Episodic overbank deposition as a dominant mechanism of floodplain and delta-plain aggradation. Geology 2015, 43, 875-878. [CrossRef]

48. Roberts, H.H. Dynamic changes of the holocene Mississippi River delta plain: The delta cycle. J. Coast. Res. 1997, 13, 605-627.

49. Blum, M.D.; Roberts, H.H. Drowning of the Mississippi Delta due to insufficient sediment supply and global sea-level rise. Nat. Geosci. 2009, 2, 488-491. [CrossRef]

50. Hensel, P.F.; Day, J.W.; Pont, D. Wetland vertical accretion and soil elevation change in the Rhone River delta, France: The importance of riverine flooding. J. Coast. Res. 1999, 15, 668-681.

51. Stanley, D.J.; Warne, A.G. Holocene sea level change and early human utilization of deltas. GSA Today 1997, $7,1-7$.

52. Giosan, L.; Woods Hole Oceanographic Institution: Woods Hole, MA, USA. Personal Communication, 2014.

53. Day, J.; Ibáñez, C.; Scarton, F.; Pont, D.; Hensel, P.; Day, J.; Lane, R. Sustainability of Mediterranean deltaic and lagoon wetlands with sea-level rise: The importance of river input. Estuar. Coasts 2011, 34, 483-493. [CrossRef]

54. Giosan, L.; Syvitski, J.; Constantinescu, S.; Day, J. Protect the world's deltas. Nature 2014, 516, 31-33. [CrossRef] [PubMed]

55. Tessler, Z.; Vörösmarty, C.; Grossberg, M.; Gladkova, I.; Aizenman, H.J.; Syvitski, J.; Fpoufoula, E. Profiling risk and sustainability in coastal deltas of the world. Science 2015, 349, 638-643. [CrossRef] [PubMed]

56. Intergovernmental Panel on Climate Change (IPCC). Climate change 2007: The physical science basis. In Contribution of Working Group I to the Fourth Assessment Report of the Intergovernmental Panel on Climate Change; Solomon, S., Qin, D., Manning, M., Chen, Z., Marquis, M., Averyt, K.B., Tignor, M., Miller, H.K., Eds.; Cambridge University Press: Cambridge, UK, 2007; p. 333.

57. Vermeer, M.; Rahmstorf, S. Global sea level linked to global temperature. Proc. Natl. Acad. Sci. USA 2009, 51, 21527-21532. [CrossRef] [PubMed]

58. Batker, D.; de la Torre, I.; Costanza, R.; Day, J.; Swedeen, P.; Boumans, R.; Bagstad, K. The threats to the value of ecosystem goods and services of the Mississippi delta. In Perspectives on the Restoration of the Mississippi Delta; Day, J., Kemp, P., Freeman, A., Muth, D., Eds.; Springer: New York, NY, USA, 2014; pp. 155-174.

59. White, J.R.; Fulweiler, R.W.; Li, C.Y.; Bargu, S.; Walker, N.D.; Twilley, R.R.; Green, S.E. Mississippi river flood of 2008: Observations of a large freshwater diversion on physical, chemical, and biological characteristics of a shallow estuarine lake. Environ. Sci. Technol. 2009, 43, 5599-5604. [CrossRef] [PubMed]

60. Rozas, L.P.; Minello, T.J.; Munuera-Fernandez, I.; Fry, B.; Wissel, B. Macrofaunal distributions and habitat change following winter-spring releases of freshwater into the Breton Sound estuary, Louisiana. Estuar. Coast. Shelf Sci. 2015, 65, 319-336. [CrossRef]

61. Tao, B.; Tian, H.; Ren, W.; Yang, J.; Yang, Q.; He, R.; Cai, W.; Lohrenz, S. Increasing Mississippi river discharge throughout the 21st century influenced by changes in climate, land use, and atmospheric $\mathrm{CO}_{2}$. Geophys. Res. Lett. 2014, 41, 4978-4986. [CrossRef] 
62. Knutson, T.R.; McBride, J.L.; Chan, J.; Emanuel, K.; Holland, G.; Landsea, C.; Held, I.; Kossin, J.P.; Srivastava, A.K.; Sugi, M. Tropical cyclones and climate change. Nat. Geosci. 2010, 3, 157-163. [CrossRef]

63. Mei, W.; Xie, S.P.; Primeau, F.; McWilliams, J.C.; Pasquero, C. Northwestern Pacific typhoon intensity controlled by changes in ocean temperatures. Sci. Adv. 2015, 1. [CrossRef] [PubMed]

64. Batker, D.; de Torre, I.; Costanza, R.; Swedeen, P.; Day, J.W.; Boumans, R.; Bagstad, K. Gaining ground: Wetlands, hurricanes, and the economy: The value of restoring the Mississippi River Delta. Environ. Law Rep. 2010, 40, 11106-11110.

(C) 2016 by the authors; licensee MDPI, Basel, Switzerland. This article is an open access article distributed under the terms and conditions of the Creative Commons by Attribution (CC-BY) license (http://creativecommons.org/licenses/by/4.0/). 